\title{
THE ANALYSIS OF PUTUKREJO VILLAGE GOVERNMENT READINESS IN FORMING BUMDES AS A DEVELOPMENT EFFORTS OF RURAL COMMUNITIES BASED ON CREATIVE ECONOMY
}

\author{
Agung Minto Wahyu ${ }^{1}$, Ega Aditya ${ }^{2}$, Navilah Laila Wardani ${ }^{3}$, Jeni Susyanti ${ }^{4}$ \\ Faculty of Economics and Business, University of Islam Malang, Indonesia \\ Email: agungminto98@gmail.com
}

\begin{abstract}
: The purpose of this study is to determine the readiness of the village government in forming BUMDes as well as the factors forming these readiness as an effort to empower rural communities based on creative economy. This study uses qualitative methods with a case study approach. The case study was conducted at BUMDes "Barokah" owned by Putukrejo Village, Gondanglegi District, Malang Regency. The results of the study confirms that the Putukrejo Village Government has a fairly good readiness in forming BUMDes. It is proven by the development of business units that are very helpful in empowering local rural communities. In addition, BUMDes "Barokah" also seeks to empower the community based on creative economy by establishing the tourist attraction, Sumber Sira Market, which is used to manage the products of the community creativity.
\end{abstract}

Keywords : Readiness, BUMDes, Community Empowerment, Creative Economy

\section{Introduction}

Based on Law No. 6 of 2014, Villages are legal community units that have territorial limits that are authorized to regulate and manage government affairs, local communities concern which based on community initiatives, origin rights, and / or traditional rights that are acknowledged and respected in the government system Negara Kesatuan Republic Indonesia (NKRI). At present, there are 83,184 villages and urban villages in Indonesia. With details of 74,754 villages and 8,430 villages. Therefore, it is undeniable that around $82.3 \%$ of Indonesia's territory is a rural (Anonymous, 2015).

In 2014, the recognition of village autonomy became more concrete with the enactment of Law No. 6 of 2014. Through the law, it is expected to encourage economic growth and empower the village communities. These efforts are not impossible to realize because based on Law No. 15 of 2017 about concerning the State Budget year 2018, village funds for the 2018 amounting to 60 trillion rupiahs have been allocated to all villages in Indonesia. With those amount, each village has received around 800 million rupiahs. The amount of funds increased when it compared to year 2015 and 2016 as shown in figure 1 above.

These realizations are essentially still in accordance with the regional development framework which is the implementation of the Nawacita program by prioritizing village development. The development is expected to support the economy and empower the rural communities. Government programs to develop and empower the village economy is continued to be intensified through Village-Owned Enterprises or Badan Usaha Milik Desa (BUMDes). Based on the reports released by indopos.co.id (2018), until June 2018, there have been 32,249 
BUMDes that are actively operating. However, not all of these BUMDes can contribute maximally in empowering rural communities which may improve the village economy. Many factors caused this to happen, one of them which is the low quality and quantity of Human Resources in the village, which has made the village government unable to effectively discover the potential economic activities of rural communities (Herry, 2015).

Empowering rural communities through BUMDes can be done based on the creative economy. BUMDes can be as a media or container to promote the products of creative economic products from the community. These products are categorized according to 16 sub-sectors which defined by Bekraf (Creative Economy Agency). Thus, it can stimulate the rural communities or villager to create the handicraft products which are can be done at home. The expectation of these is to reduce unemployment and rural urbanization.

On the other hand, the government's efforts to optimize the establishment of the BUMDes are in accordance with Law No. 6 of 2014 concerning Villages, village facilitators are formed to increase capacity, effectiveness, accountability, facilitate and assist village governments in planning village development to run well and increase creativity, community participation in village development. However, the fact found in field was the powerlessness of the village because the village government was not ready to explore the potential of the village. As an effect, the village government has difficulty in allocating village funds to form BUMDes that can empower rural communities.

Suwadji (2018) explained that currently in Malang Regency there are only 100 villages that has active BUMDes in Malang City.Whereas in Malang Regency there are a total of 378 villages, therefore it can be concluded that there are around 278 villages that do not have BUMDes. It is targeted that 70-80 percent of villages in Malang Regency already have BUMDes in 2018 (Radar Malang, 2018). One of the active BUMDes in Malang Regency is BUMDes "Barokah" owned by Putukrejo Village, Gondanglegi District, Malang Regency. BUMDes "Barokah" is engaged in several business units, including savings and loans, tourism, up to unit production and service whose cash flows from all business units range from Rp 300 million to Rp 500 million per year (Jawapos, 2018).

\section{Literature Review}

\subsection{Readiness of the Village Government in Establishing BUMDes}

According to Armenakis et al (in Herlina, 2013) interpreting readiness is as a marker of the ability to think of behaviors of rejection or support for efforts to change. According to Hendri et al (2016) the readiness of the village government is the ability of the village apparatus to prepare their personal abilities and the ability of the village apparatus to look for potential financial resources.

The educational aspect influences the readiness of the village government, according to Kusuma (in Hendri et al, 2016) people who are more educated have greater opportunities to be able to work effectively and efficiently. The readiness of the village government is the ability of the village government to cognitively deal with changes for possible improvements and the ability of the village government to find potential village resources.

Village governments that are ready will be able to easily find potential new village financial resources. The establishment of BUMDes is based on village needs and potential as an effort to increase community welfare. BUMDes are built on community initiation, which is based on the principles of cooperation, participatory, emancipatory, transparency, accountable, and sustainable with member-based mechanisms and independent business (Ridlwan, 2014). 
International Journal of Economics, Business and Accounting Research (IJEBAR) _

Peer Reviewed - International Journal

Vol-3, Issue-3, 2019 (IJEBAR)

E-ISSN: 2614-1280 P-ISSN 2622-4771

http://jurnal.stie-aas.ac.id/index.php/IJEBAR

\subsection{Badan Usaha Milik Desa (BUMDes)}

According to Law No. 6 of 2014 concerning Villages, Badan Usaha Milik Desa (BUMDes) are business entities whose entire or part of their capital fund is owned by the Village through direct participation originating from village assets which are separated since for manage assets, services and businesses and others for the greatest welfare of the village community. In short, the definition of Badan Usaha Milik Desa (BUMDes) is stated in section 1 of article 6 of the Peraturan Menteri dalam Negeri No. 39 of 2010 concerning Village-Owned Enterprises, which states that BUMDes are village businesses which formed / established by village governments whose capital ownership and the management is carried out by the village government and the community.

BUMDes are built on initiatives (community initiation), and are based on cooperative, participatory and emancipatory principles, with two underlying principles, namely member base and self help (Ramadana, 2013). As an embodiment of village productive economic management, the establishment and management of Badan Usaha Milik Desa (BUMDes) must be carried out in a participatory, cooperative, accountable, transparent, sustainable and emancipatory manner. Therefore, the management of the business entity must be taken seriously and hence it can run effectively, efficiently, professionally, independently so that it can improve the welfare of the village community. In addition, the ability of the village apparatus to prepare personal capabilities and search for potential financial resources will greatly affect the readiness of the village government (Herry, 2015).

In an effort to achieve the intention of Village-Owned Enterprises (BUMDes), the community and the Village Government as managers can comply the needs of (productive and consumptive) communities through the distribution of goods and services. According to article 6 of the 2014, concerning Villages, the Establishment of Village-Owned Enterprises (BUMDes) must be carried out according to the needs and potential of the village. BUMDes management must also be carried out with a proper concept, including the transparency to the community, accountability in accordance with the rules and applicable law, the community must be actively involved in BUMDes. Despite, BUMDes must provide benefits to the community (Solekhan in Chintary, 2016)

Some activities before establish BUMDes for make it run optimally and have a positive impact on the prosperity of rural communities (The Guidebook for the Establishment and Management of Village Owned Enterprises, 2007) as follows:

a. Designing organizational structures.

b. Arrange job descriptions.

c. Establish a coordination system.

d. Develop cooperation policies.

e. Develop work guidelines.

f. Arrange information system design.

g. Develop a business plan.

h. Develop a system of administration and accounting.

i. Conduct recruitment process.

j. Establish a payroll and wage system.

Economically, BUMDes are expected to be able to stimulate and drive the economy in rural areas. The economic assets in the village must be fully managed by the village community. BUMDes will move in tune with efforts to increase the sources of village pristine income, move the economic activities of the community where the role of BUM Desa as umbrella institutions in shading (Nurcholis, 2011). 
Politically, BUMDes which stand in a participatory manner are a meeting place for group of people who has interest in the village. Agreements regarding the type of business, the percentage of profit sharing, and the issuance of village regulations (PERDES) are among the indirect benefits of the existence of BUMDes. Anually, the BUMDes administrators carry out accountability reports that are attended by representatives of community elements as a form of transparency and accountability in business management. There the community carries out a control (supervision) function on the business operations of the business units under the BUMDes and discusses the planning to be carried out in the next fiscal year.

In a socio-cultural way, BUMDes will create a new entrepreneurial culture for rural communities so it will encourage the movement of the village economy. Entrepreneurial village development offers a solution to reduce poverty, population migration, and employment development in the village. Entrepreneurship becomes a strategy in develop and growth the community welfare, where resources and facilities are provided spontaneously by (community) rural communities to lead to changes in rural socio-economic conditions (Ansari, 2013). The development of entrepreneurship can be started through creative economy that can be done by every villager in their homes.

\subsection{Creative Economy}

Creative economy as an economic concept that prioritizes information and creativity by relying on ideas and stock of knowledge from Human Resources (SDM) in its economic activities (Askandar, 2017). Howkins (on Askandar, 2017) mentions new economies have emerged around the creative industry that are controlled by intellectual property laws such as patents, copyrights, brands, royalties, and designs. The structure of the world economy is undergoing a rapid transformation along with economic growth, from Natural Resources (SDA)-based to SDMbased, from the agricultural era to the industrial and information era.

The Creative Economy Subsector wich has developed in Indonesia and received serious attention from BEKRAF, consists of application and game development, architecture, interior design, visual communication design, product design, fashion, film, animation and video, photography, crafts, culinary, music, publishing, advertising, performing arts, fine arts, television and radio.

\section{Research Methods}

This study uses a qualitative method. According to Moleong (2014), qualitative research is a scientific research that aims to understand a phenomenon or case about what is experienced by research subjects. The approach used in this study is a case study. Herdiansyah (2015) states that a case study is a qualitative research model that is detailed about an individual or a particular social unit over a period of time. Furthermore, case studies is comprehensive, intense, detailed, profound, and more directed model as an effort to examine problems or phenomenon that is contemporary. In case study, the researcher intends to find the uniqueness of the case so that it focused the questions towards its process and cause. In addition, researchers can also write the follow-up questions that are focused on the issues of topic under the study.

The selected case study design is a collective case study conducted to draw conclusions or generalizations towards the phenomenon or population of these cases (Herdiansyah, 2015). This case study focuses on looking at the readiness of the Putukrejo village government in forming bumdes as an effort to empower rural communities based on creative economy. The Research location is in Putukrejo Village, Gondanglegi, Malang Regency. This study used 4 participants who were carried out with side snowball techniques. The snowball sampling technique is a 
International Journal of Economics, Business and Accounting Research (IJEBAR) _

Peer Reviewed - International Journal

Vol-3, Issue-3, 2019 (IJEBAR)

E-ISSN: 2614-1280 P-ISSN 2622-4771

http://jurnal.stie-aas.ac.id/index.php/IJEBAR

method for identifying, selecting and taking samples in a network or continuous row of relationships (Neuman, 2003).

Data collection is done by observation and semi-structured interviews. The collected data is then analyzed by reducing data, presenting data, and inferring the results of the study (Sugiyono, 2012). Furthermore, the researchers will check the validity data by testing the credibility through triangulation.

\section{Result and Discussion}

\subsection{Readiness of the Village Government in Establishing BUMDes}

Based on the interviews conducted by researchers with the subject, namely the chairman of BUMDes "Barokah", Putukrejo Village and the Head of Putukrejo Village, Gondanglegi District, Malang Regency, information was obtained about the readiness of the village government in dealing with the changes. From these changes, the village government is expected to remain capable of finding potential village sources that can increase Pendapatan Asli Desa (PAD).

“...perubahan yang signifikan kan terjadi tahun 2014 ketika ada program dana desa yang besar itu, atas amanat undang-undang maka kami berinisiatif mendirikan BUMDes untuk kemaslahatan masyarakat..." (S2).

The Putukrejo Village Government does not make village funds a burden which then raises fears in its management. Although it still must be recognized at the outset of the village funds there were difficulties in its use, but over time the Government of the Putukrejo Village was able to adapt to this.

“...memang awal-awal ada ketakutan karena ketika bimtek dan pelatihan itu gak sama dengan dulu sebelum 2014, kalau setelah 2014 ini ya kalau ada pelatihan dan bimtek itu narasumbernya kejaksaan, kepolisian, BPK, inspektorat. Sehingga ketakutan itu memang ada, tapi berjalannya waktu karena kita sudah memahami, yaa kita belajar sebaik-baiknya, sehingga saya lihat setelah itu memang pembukuan itu bagus.." (S2).

Having been able to manage village funds well and then allocate to several fields. Based on the realization of the use of village funds until 2017, most village funds are used for village infrastructure development (Ministry of Finance, 2017). No exception also in Putukrejo Village, but the Putukrejo Village Government will also prioritize infrastructure development that can support the existence of Sumbersira Tourism as one of the main business units in BUMDes Barokah. This is done to facilitate access of tourists who will visit Sumbersira.

“...ya ini memang menjadi tujuan pokok kan masih banyak infrastuktur yang belum kita kita tangani. Pembangunan tersebut terutama yang paling kita fokuskan di wisata, karena apa? karena kita membangun infrastuktur disana tentunya ada income yang didapatkan desa...” (S2).

According to the management, the establishment of the BUMDes is inseparable from the role of the village government that is able to provide solutions to any problems faced during the formation of these BUMDes.In addition, the village government is also able to gather community aspirations through deliberation.

“...tapi kadang-kadang kan bingung apa yang harus kita lakukan, jadi melalui pemerintah desa dan musyawarah kemudian berdirilah yang namanya BUMDes Barokah..." (S1).

The readiness of the village government in establishing the BUMDes is evidenced in its ability to carry out activities during the establishment of the BUMDes as follows. 
International Journal of Economics, Business and Accounting Research (IJEBAR) _

Peer Reviewed - International Journal

Vol-3, Issue-3, 2019 (IJEBAR)

E-ISSN: 2614-1280 P-ISSN 2622-4771

http://jurnal.stie-aas.ac.id/index.php/IJEBAR

\subsection{Designing the organizational structures}

Since the start of the BUMDes Barokah, the Putukrejo Village Government has been able to design the organizational structure in BUMDes. The organizational structure is made lean so that it is more efficient and easy to coordinate which consisting of three supervisors, advisors (village heads), heads, secretaries, treasurers, and four unit heads.

"...secara keseluruhan struktur BUMDes ini kan memang ramping, selain itu ada beberapa unsur usaha tapi kita gabungkan jadi satu unit agar lebih efisien...” (S1).

The merging of several business elements into one business unit is carried out so that the business elements that have developed can cover the operational costs of the business elements that have just been initiated. The merger is for example in the Savings and Loan Business Unit, Business, Service Production and skills.

“...kalau kita terlalu banyak unit tapi ternyata pemasukannya masih sangat sedikit ini kan tidak bisa menutupi kebutuhan operasionalnya...” (S1).

\subsubsection{Arrange the job descriptions}

The preparation of job descriptions is tailored to each existing business unit. However, the job description is made more flexible. Especially in business units that have different business elements. This also allows employees in the business unit to do work on more than one business element.

“...kita menyesuaikan dengan beberapa unit usaha, artinya misalnya contoh kalau di unit wisata tentu apa yang menjadi tugas di unit wisata...” (S1).

Furthermore, the reason for the description of the work being made more flexible is also influenced by the compensation obtained by the workforce at BUMDes Barokah.

"...kita belum bisa membuat secara profesional karena ketika kita melaksanakan sebuah aturan yang profesional bayarannya juga kan harus profesional...." (S1).

\subsubsection{Establish the coordination system}

Coordination systems are formed to unite partial objectives into a general purpose. In the initial stages of formation, more coordination systems are carried out using a family approach. However, the kinship approach remains in the structural system within the BUMDes Barokah.

“...kami awalnya lebih menekankan koordinasi dengan pendekatan kekeluargaan. tujuannya adalah agar dapat membangun solidaritas dengan cepat. Meskipun begitu, koordinasi secara struktural juga tetap dilakukan...." (S1).

\subsubsection{Develop the cooperation policies}

Cooperation policies concerning business elements in each business unit are formulated in clear and mutually beneficial rules. The cooperation policy is carried out both horizontally with the district government and the central government and vertically with BUMDes and other institutions.

“...potensi yang ada di desa ini khususnya wisata Sumbersira kemudian juga kami diskusikan dengan pemerintah kabupaten. Berkat itu pula kita dengan pemerintah kabupaten melakukan kerja sama dalam hal promosi..." (S1).

Cooperation with the government is not only related to business units. But it also relates to training and development of human resources as follows.

“...kami merupakan salah satu dari 10 orang yang di utus oleh pemerintah kabupaten Malang untuk mengikuti akademi desa yang di gagas oleh pak menteri (PDTT)...” (S1). 
International Journal of Economics, Business and Accounting Research (IJEBAR) .

Peer Reviewed - International Journal

Vol-3, Issue-3, 2019 (IJEBAR)

E-ISSN: 2614-1280 P-ISSN 2622-4771

http://jurnal.stie-aas.ac.id/index.php/IJEBAR

BUMDes Barokah has also formed a partnership with Bank Rakyat Indonesia (BRI). From this collaboration, the BUMDes often receive the Corporate Social Responsibility (CSR) funds.

“...Alhamdulillah bahkan hari ini kita sudah kerjasama dengan BRI..." (S1).

Other than BUMDes, they are also often cooperate with other institutions. Although the collaboration is not all done formally. However, the benefits can be felt directly.

“...dalam acara-acara tertentu, kami biasanya bekerjasama dengan BUMDes lain dalam

mendirikan stand-stand untuk pameran produk-produk BUMDes...” (S1).

\subsubsection{Develop work guidelines}

The formulation of work guidelines is formulated in coorperation with related parties and manifested afterwards in the Articles of Association / Bylaws (AD / ART) of BUMDes Barokah. The AD / ART is then used as a reference for managing in accordance with the principles of BUMDes governance.

“...pada awal pendirian BUMDes ini dulu, kami merumuskan secara bersama-sama AD/ART

untuk kemudian dijadikan landasan dalam menjalankan BUMDes ini ke depan...” (S2).

\subsubsection{Arrange information system design}

As a village institution that has an open trait, it is necessary to design a system for providing information on the performance of BUMDes.

"...semua perkembangan dalam BUMDes ini kami berusaha kelola secara transparan agar masyarakat juga dapat turut serta mengawasi...” (S2).

A good information system is expected to be able to build community trust in BUMDes Barokah. The information system has begun to utilize digital technology through the website. The aim is to make it easier for the public to access all information contained in the BUMDes Barokah.

“...saat ini semua perkembangan yang ada dalam BUMDes Barokah bisa diakses melalui website (www.bumdesabarokah.com)...”(S1).

\subsubsection{Develop a business plan}

The preparation of business plans is mostly done on the basis of the potential that already exists. Then the potential is adjusted to the needs of the people of Putukrejo Village, which are the most curcial needs and the economic prospects.

“...beberapa unit usaha memamg sudah ada sebelum adanya BUMDes ini...” (S1).

Potentials that exist in BUMDes Barokah, are clean water facilities and Sumbersira tourism. From these potential units, they are further developed into various other business units. The development is for instance by providing subsidized fertilizer for farmers.

"...sarana air bersih ini yang memang berpotensi sejak beberapa tahun yang lalu dan saat ini sudah bisa melayani sepuluh desa di dua kecamatan...” (S1).

Besides, BUMDes Barokah established other supporting business units such as savings and loans, photocopying, production services and skills. Until now, BUMDes have owned five business units.

\subsubsection{Develop a system of administration and accounting}

The establishment of a financial administration and accounting system is carried out in a simple and easy format, but it is able to describe the activities carried out by BUMDes. Although initially the BUMDes management had difficulties in compiling the administration and 
International Journal of Economics, Business and Accounting Research (IJEBAR) _

Peer Reviewed - International Journal

Vol-3, Issue-3, 2019 (IJEBAR)

E-ISSN: 2614-1280 P-ISSN 2622-4771

http://jurnal.stie-aas.ac.id/index.php/IJEBAR

bookkeeping system, but over time the BUMDes administrators were able to make and present good financial administration and accounting.

“...kita belajar sebaik-baiknya, seiring berjalannya waktu karena kita sudah memahami sehingga

saya lihat setelah itu memang pembukuan itu bagus dan juga memberi pelajaran kita untuk hati-hati...." (S2).

Until now, the administration and bookkeeping system in BUMDes has been running well and structured.

“...secara keseluruhan kita bisa menyesuaikan dan bisa melaporkan semua kegiatan tiap tahun,

bahkan kita rutin setiap bulan, setiap tiga bulan ada rapat kordinasi, evaluasi dan sekaligus pelaporan...."

(S1).

\subsubsection{Conduct recruitment process}

The recruitment process was carried out to find people who would later become managers of BUMDes Barokah. The recruitment system is carried out by deliberation while still basing on certain criteria required by BUMDes Barokah. The criteria intended are required to the employee in order to carry out their duties well according to their job descriptions.

“...rekrutmen di BUMDes ini kita buat dengan mengedepankan musyawarah, meskipun begitu

tetap berpedoman pada kriteria yang dibutuhkan dalam BUMDes...” (S1).

The recruitment at BUMDes Barokah prioritizes the people of Putukrejo Village. To make things easier, the recruitment is involving the organizations in Putukrejo Village such as Karang Taruna. Therefore, the existence of BUMDes Barokah will be able to provide jobs so as to reduce urbanization and unemployment in Putukrejo Village. In addition, the benefits which can directly felt by the Putukrejo Village is the increasement of the trusts and supports of the community towards the running of the BUMDes Barokah.

“...kami melakukan rekrutmen terutama teman-teman muda asli desa, seperti teman-teman

karang taruna yang memiliki kemampuan maka kita rekrut....” (S2).

Furthermore, for now the recruitment is no longer carried out. It is because the number of workers on BUMDes Barokah is sufficient. The employment is open only when there are workers who leave and so new workers need to fill the empty position. However, the BUMDes management hoped that the business unit at BUMDes Barokah would continue to grow and expand so that it could also employ more people in the village of Putukrejo.

“...kita melihat kebutuhan di dalam BUMDes, di masing-masing unit bisnis apakah ada

kebutuhan untuk tenaga kerja apa tidak, kalau selama ini belum ada ya kita belum ya bisa rekrut orang lagi,..." (S1).

\subsubsection{Establish a payroll and wage system}

Payroll or wages are given in order to motivate workers to carry out their duties. Currently, BUMDes Barokah is not using a fixed salary system. However, it still uses the term bisyaroh or a kind of wages given as a form of compensation for the work that has been done.

“...istilahnya disini hanyalah Bisaroh...” (S1).

The term compensation is in the form of Bisyaroh because the term salary has not been able to be applied. Hence, some new business units have not been able to support their own finances.

“...nah pada beberapa unit bisnis yang baru pendapatannya belum mampu menutupi pengeluarannya, maka dari itu sistem penggajiannya kita pilih istilah bisyaroh..." (S1).

The amount of bisyaroh that the workers get depends on the income received from each 
International Journal of Economics, Business and Accounting Research (IJEBAR) .

Peer Reviewed - International Journal

Vol-3, Issue-3, 2019 (IJEBAR)

E-ISSN: 2614-1280 P-ISSN 2622-4771

http://jurnal.stie-aas.ac.id/index.php/IJEBAR

business unit. The higher revenue of the business unit obtained, the higher bisyaroh the worker received. So it can be concluded that the bisyaroh received by each worker is not the same with each other. It depends on the amount of income received by the business unit where he works.

“...bisyaroh yang diterima tergantung unit bisnis tempat bekerja, jadi tidak sama..." (S1).

\subsection{Factors Affecting Village Government Readiness in Establishing BUMDes}

Based on interviews conducted by researchers, the factors that influence the readiness of the village government in forming BUMDes were obtained. These factors should be owned by every BUMDes if they want to succeed in managing their business units. These factors include the following.

\subsubsection{The ability to manage the Village Budget and Allocation Fund (ADD) optimally}

The first factor that can make the village government able to form BUMDes well is the ability to manage the APBDes and ADD optimally. In this case the village government is expected to be able to divide the APBDes and ADD in percentages according to the priorities of each village. In that priority, of course, there must also be a percentage for BUMDes. In addition, the main priority for infrastructure development is also expected to support the existence of business units in BUMDes.

The main capital of BUMDes Barokah in Putukrejo Village comes from the Regional Budget and ADD. Then the rest comes from joint ventures and investments from third parties.

\subsubsection{The ability to find access to capital from sources other than APBDes and ADD.}

This capability is the second factor that can affect the readiness of the village government in forming BUMDes. According to Kamaroesid (2016), the initial capital of BUMDes came from the APBDes, then assisted by the inclusion of village capital consisting of private sector grants, community social economic institutions, government assistance, business cooperation with the private sector, and village assets submitted to APBDes according statutory provisions. In addition, the capital of BUMDes can also come from the participation of capital of the village community which consists of community savings.

The additional capital of BUMDes Barokah owned by Putukrejo Village comes from stateowned enterprises and villagers' savings. However, the policy taken by the BUMDes Barokah management was to limit the amount of capital injected from the private sector in large numbers. This was done to anticipate the existence of restrictions on sovereignty in terms of management carried out by the Putukrejo Village Community if there were other parties who controlled the capital of the BUMDes Barokah in large numbers. Although this policy has slightly hampered the development of the BUMDes Barokah more quickly, this policy is believed as the appropriate system to be implemented in the BUMDes Barokah because the community can manage the BUMDes themselves without much intervention from other parties.

\subsubsection{The ability to identify potential within the village.}

The identification of potential within the village is certainly the main thing that needs to be done in establishing BUMDes. Identification of the potential of the village becomes the basis for determining the business units to be formed in an BUMDes. In identifying the potential of the village, the village government must have a clear ability to recognize village potential that has good prospects to be realized in the business units at BUMDes.

The village potential that was successfully met was then formulated together with the villagers to determine the alternative design of the business unit and classification of business types. The classification of BUMDes business types generally consists of serving, banking, 
International Journal of Economics, Business and Accounting Research (IJEBAR) _

Peer Reviewed - International Journal

Vol-3, Issue-3, 2019 (IJEBAR)

E-ISSN: 2614-1280 P-ISSN 2622-4771

http://jurnal.stie-aas.ac.id/index.php/IJEBAR

brokering and renting, trading, and holding (Kamaroesid, 2016).

These types of businesses are almost all run within BUMDes Barokah. For serving businesses, BUMDes now have business units in providing clean water and sanitation facilities. Then the type of banking business namely BUMDes Barokah has a savings and loan business unit for the surrounding community. BUMDes Barokah also has a type of trading business in the form of an agricultural and fisheries business unit which sells agricultural and fishery products. The last type of holding is business in the form of a sira source tourism unit.

\subsubsection{The ability to gather aspirations regarding the needs of the local community.}

The success of the Putukrejo Village Government in recognizing village potential is also inseparable from the role of the local community who always give their aspirations. In this case, it means that the village government is able to provide media for the community to voice their aspirations. According to article 5 point A of the 2010 Regulation of the Minister of Home Affairs number 39, said that the establishment of BUMDes is based on the initiative of the village government and or the community based on consensus agreement. From this statement, it can be said that the formation of business units in BUMDes can be done by a combination of ideas from the village government and the community.

\subsubsection{The ability to move organizations in the village.}

The main component in the success of the BUMDes is to mobilize organizations in villages such as the Youth Organization and Farmers' Groups. This is done because almost all the people in the village usually have joined these organizations. Such as Karang Taruna, where the organization oversees village youth activities. It will be much easier through Karang Taruna to mobilize young people to participate in BUMDes activities rather than having to move the youth personally. Likewise the Farmer Group is very useful to support the running of the agricultural and fisheries business units.

Most of the human resources, especially young people in Putukrejo Village are members of the Karang Taruna. Therefore, at the beginning of its formation, BUMDes Barokah first mobilized Karang Taruna to run a business unit within the BUMDes. Then the BUMDes slowly carried out professional recruitment of existing human resources in the Karang Taruna to become laborers in the BUMDes Barokah.

\subsubsection{The ability to establish relationships, both horizontally and vertically.}

In running a business, building relationships with various parties is a necessity. These relationships are very useful in developing a business that is run. Including the BUMDes, as a business entity managed by the village government.

Cooperation in BUMDes can be done horizontally and vertically. Horizontally, BUMDes can collaborate with equal parties such as other BUMDes, community social institutions, and other village institutions. Whereas vertically, BUMDes can work with parties that are higher or lower in position, for example the district/city government, provincial government, central government.

Village governments that are unable to establish relationships with various parties will find it very difficult to develop their BUMDes. Various relationships will be beneficial for BUMDes in developing their business. 
International Journal of Economics, Business and Accounting Research (IJEBAR) . Peer Reviewed - International Journal

Vol-3, Issue-3, 2019 (IJEBAR)

E-ISSN: 2614-1280 P-ISSN 2622-4771

http://jurnal.stie-aas.ac.id/index.php/IJEBAR

\subsubsection{The ability to form a qualified Board of BUMDes.}

In activities while preparing for the establishment of BUMDes, one of the things that must be done is to form a board that will manage BUMDes. The formation of the BUMDes board in a village is certainly not an easy thing. The obstacle is the difficulty of finding qualified human resources in the village. Therefore, not all village governments are able to form a qualified board of BUMDes. Besides in terms of cognitive abilities, the village government must also consider power strugle, sincerity, honesty in recruiting the management of the BUMDes.

\subsection{Empaworing Village Communities through BUMDes based on Creative Economy.}

The development of the village's creative economy through BUMDes is based on the potential of product design, photography, craft arts besides existing ones, culinary. Product design is the process of creating a product that combines elements of function with aesthetics so that it is useful and has added value to the village community by exploring and elevating local wisdom, village cultural wealth in each work.

Photography is an art or process of produces images and light in a film. The development of the photography sub-sector strongly supports the young generation who are very enthusiastic about learning photography, tourism development and village culture.

Craft art is one of the sub-sectors that are close to the tourism industry. Judging from the material, the craft includes all crafts made from wood, metal, leather, glass, ceramics and textiles. The availability of abundant raw materials in the form of wood in the village and HR creativity strongly supports craft arts.

Culinary which is a regional food and beverage is a part of the creative economy, the culinary sub-sector contributes quite significantly, which is $30 \%$ of the total income of the tourism sector and the creative economy. Recently, the growth of the creative economy industry in Indonesia showed a positive graph. The emergence of new startups in the world of creative industries shows a strong commitment from the Government to boost economic growth from the Creative Economy sector. The Indonesia Creative District / City Independent Ranking Team (PMK3I) under the auspices of the Indonesian Creative Economy Agency (Bekraf) continuously conducts stringent tests on the aspects of Creative Economy in each Regency / City in Indonesia which at the end can be strengthened by the initiation of a creative economy through BUMDes.

BUMDes Barokah as one of the BUMDes in Malang Regency responds to the potential development of BUMDes through a creative economy, one of which is by establishing the Sumber Sira Tourism Market. Where the tourist market is located near by the Sumber Sira Tourism Unit.

Sumber Sira Tourism Market aims to accommodate all the results of the creativity of the village community to then be marketed to the villagers themselves and tourists who visit the Sira source. The results of such creativity mostly include product design, photography, craft arts, and culinary which are part of the sub-sector in the creative economy. The existence of the tourism market is expected to empower the surrounding village communities that are not formally accommodated in BUMDes.

\section{Conclusion}

Based on the explanation of the previous discussion. It can be concluded that the readiness of the village government can be seen from the ability to find potential sources of the village which can increase Pendapatan Asli Desa (PAD). One of these abilities can be seen from its success in forming BUMDes. In preparing the establishment of the BUMDes, the activities that must be carried out by the village government are designing the organizational structure, compiling job 
descriptions, establishing a coordination system, compiling cooperation policies, drafting work guidelines, compiling information system designs, compiling business plans, compiling administrative and accounting systems, carrying out the recruitment process, and establish payroll and wage systems.

The factors that influence the readiness of the village government are the ability to manage the Village Budget and Allocation Fund (ADD) optimally are the ability to seek access to capital from other sources besides the APBDes and ADD, the ability to identify potential in the village, the ability to gather aspirations regarding the needs of the local community, the ability to move the organization within the village, the ability to establish relationships, both horizontally and vertically, and the ability to form a qualified Board of BUMDes.

To empower rural communities, management of BUMDes can be done based on a creative economy. The development of the village's creative economy through BUMDes is based on the potential of covering, product design, photography, craft arts besides existing ones, namely culinary. BUMDes "Barokah" as one of the BUMDes in Malang Regency responds to the potential development of BUMDes through a creative economy by establishing the Sumber Sira Tourism Market. Sumber Sira Tourism Market aims to accommodate all the results of the creativity of the village community to then be marketed to the villagers themselves and tourists who visit the Sumber Sira.

\section{References}

. 2018. BUMDes Barokah Beromzet Rp 500 Juta. (Online), (https://www.jawapos.com/_) Diakses 11 Juli 2019.

Askandar, N. S. dan Jeni Susyanti. 2017. Menuju Wirausaha Mandiri. Malang:BPFE Unisma

Chintary, V.Q. dan Lestari A.W. 2016. Peran Pemerintah Desa dalam Mengelola Badan Usaha Milik Desa (BUMDes). JISIP : Jurnal Ilmu Sosial dan Ilmu Politik 5 (2) : 59-63.

Fajarwati, F. 14 Maret 2018. 278 Desa Ditarget Miliki BUMDes. Jawa Pos. (Online), (http://www.radarmalang.id/_)

Hendri, S. dkk. 2016. Pengaruh Sumber Daya Manusia, Sarana dan Prasarana terhadap Kinerja Pengelolaan Keuangan Desa di Kabupaten Lombok Tengah. Conference on Management and Behavioral Studies, Universitas Tarumanegara, Jakarta, 2016.

Herdiansyah, H. 2015. Metodologi Penelitian Kualitatif untuk Ilmu Psikologi. Jakarta:Salemba Humanika.

Herry, A. 2015. Kesiapan Desa Menghadapi Implementasi Undang-Undang Desa. Jurnal Ilmiah CIVIS 5 (1).

Indopos. 4 Juni 2018. Ada 32.249 BUMDes Aktif di Indonesia. (Online), (https://indopos.co.id/_). Diakses 10 Juli 2019

Kementerian Keuangan Republik Indonesia. Kebijakan Pengalokasian dan Penyaluran Dana Desa Tahun 2017. Jakarta:

Moleong, L. J., 2014. Metodologi Penelitian Kualitatif. Bandung: Remaja Rosdakarya.

Nurcholis, H., 2011, Pertumbuhan dan Penyelenggaraan Pemerintahan Desa. Jakarta: Penerbit Erlangga.

Peraturan Menteri dalam Negeri Nomor 39 Tahun 2010 Tentang Badan Usaha Milik Desa.

Pusat Kajian Dinamika Sistem Pembangunan. 2007. Buku Panduan Pendirian dan. Pengelolaan Badan Usaha Milik Desa. Jakarta:Departemen Pendidikan Nasional.

Ramadana A, dkk. 2013. Keberadaan Badan Usaha Milik Desa (Bumdes) Sebagai Penguatan Ekonomi Desa (Studi di Desa Landungsari, Kecamatan Dau, Kabupaten Malang. Jurnal 
International Journal of Economics, Business and Accounting Research (IJEBAR) _

Peer Reviewed - International Journal

Vol-3, Issue-3, 2019 (IJEBAR)

E-ISSN: 2614-1280 P-ISSN 2622-4771

http://jurnal.stie-aas.ac.id/index.php/IJEBAR

Administrasi Publik (JAP) 1 (6) : 1068-1076

Sugiyono. 2012. Metode Penelitian Pendidikan Pendekatan Kuantitatif, Kualitatif, dan R\&D.

Bandung: Alfabeta.

Undang-Undang Nomor 6 Tahun 2014 tentang Desa.

Undang-Undang Nomor 15 Tahun 2017 tentang Anggaran Pendapatan dan Belanja Negara Tahun Anggaran 2018. 